\title{
Confirmation of the first report of Psammolestes tertius Lent and Jurberg, 1965 (Hemiptera, Reduviidae, Triatominae) in Paraná State, Brazil
}

\author{
Vinícius Fernandes de Paiva ${ }^{[1]}$, João Aristeu da Rosa ${ }^{[2]}$, Walter Ceretti Junior ${ }^{[3]}$, \\ Mauro Toledo Marrelli ${ }^{[3]}$ and Jader de Oliveira ${ }^{[2,3]}$
}

[1]. Universidade Estadual de Campinas, Instituto de Biologia, Departamento de Biologia Animal, Campinas, SP, Brasil.

[2]. Universidade Estadual Paulista Júlio de Mesquita Filho, Faculdade de Ciências Farmacêuticas,

Departamento de Ciências Biológicas, Araraquara, SP, Brasil.

[3]. Universidade de São Paulo, Faculdade de Saúde Pública, São Paulo, SP, Brasil.

\begin{abstract}
Introduction: This study confirms the occurrence of Psammolestes tertius Lent \& Jurberg, 1965 (Hemiptera, Reduviidae, Triatominae) in the state of Paraná, Brazil. Methods: In 2002, a male specimen of P. tertius was collected in the municipality of Porto Rico, Paraná, Brazil. Results: This finding adds to the data on the geographical distribution of $P$. tertius from 14 to 15 known occurrences in Brazilian states and, therefore, reports the increase in the diversity of triatomines in Paraná. Conclusions: The presence of $P$. tertius in the state of Paraná demonstrates that the biodiversity of these insects may have been underestimated.
\end{abstract}

Keywords: Triatomines. Chagas disease. Occurrence.

The subfamily Triatominae is established as its members are important vectors of Trypanosoma cruzi (Chagas, 1909), the etiologic agent of Chagas disease. Currently, the subfamily comprises more than 150 species grouped into 19 genera ${ }^{1}$. The genus Psammolestes (Bergroth, 1911) includes three species: Psammolestes coreodes (Bergroth, 1911), Psammolestes arthuri (Pinto, 1926), and Psammolestes tertius (Lent and Jurberg, 1965); however, the role of these species in the epidemiology of human diseases remains uncertain ${ }^{2}$.

The genus Psammolestes has a close association with the nests of some species of birds belonging to the families Dendrocolaptidae, Troglodytidae, Furnariidae, and Icteridae ${ }^{3,4,5,6}$. This close association suggests that birds are their only source of food ${ }^{2,7}$.

Corresponding author: Dr. Jader de Oliveira.

e-mail: jdr.oliveira@hotmail.com

(D) https://orcid.org/0000-0002-2588-1911

Received 20 July 2020

Accepted 11 August 2020
In the state of Paraná, researchers have reported the occurrence of nine species: Panstrongylus megistus (Burmeister, 1835); Panstrongylus geniculatus (Latreille, 1811); Triatoma arthurneivai (Lent and Martins, 1940); Triatoma sordida (Stal, 1859); Rhodnius neglectus (Lent, 1954); Rhodnius domesticus (Neiva and Pinto, 1923); Cavernicola pilosa (Barber, 1937); Microtriatoma borbai (Lent and Wygodzinsky, 1979); and, Triatoma tibiamaculata (Pinto, 1926) $)^{8,9,10}$.

The occurence of P. tertius has been recorded in Brazil (Minas Gerais, São Paulo, Goiás, Mato Grosso, Pará, Tocantins, Alagoas, Bahia, Ceará, Maranhão, Paraíba, Pernambuco, Piauí, and Rio Grande do Norte) and Peru (San Martín) ${ }^{10,11,12}$.

At the Brazilian Congress of Entomology, Silva et al. 2004 ${ }^{13}$ presented the first record of $P$. tertius in the state of Paraná. However, according to Article 9.10 of the International Code of Zoological Nomenclature ${ }^{14}$, summary presentations at congresses do not constitute published work; therefore, this summary was not considered by other studies indicating the occurrence of the species in the state of Paraná ${ }^{6,9,10}$. A male specimen of $P$. tertius (Figure 1) was collected in the municipality of Porto Rico (Figure 2) in a bird's nest (Furnariidae) on Mutum Island, Paraná River, Paraná, Brazil on 


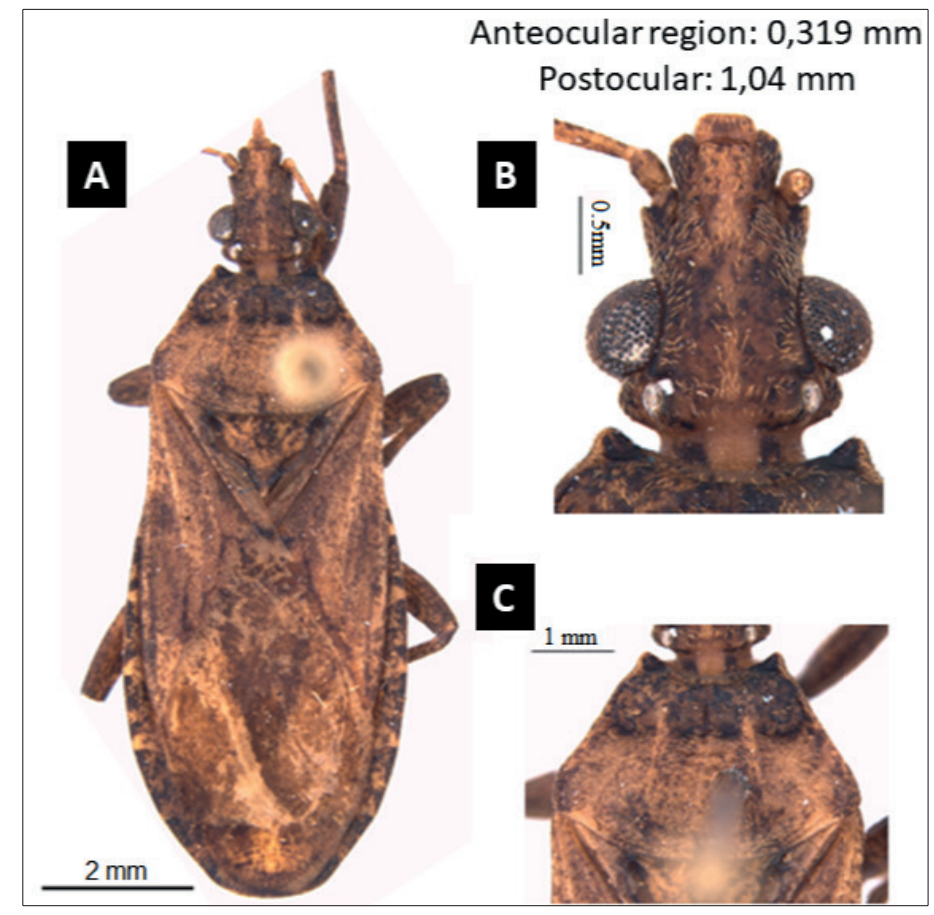

FIGURE 1: (A) Dorsal view of the specimen; (B) Detail of the head in dorsal view; and,(C) Detail of the pronotum in dorsal view; scale bar: A: $2 \mathrm{~mm}$; B: 0.5 $\mathrm{mm}$; and, C: $1 \mathrm{~mm}$.

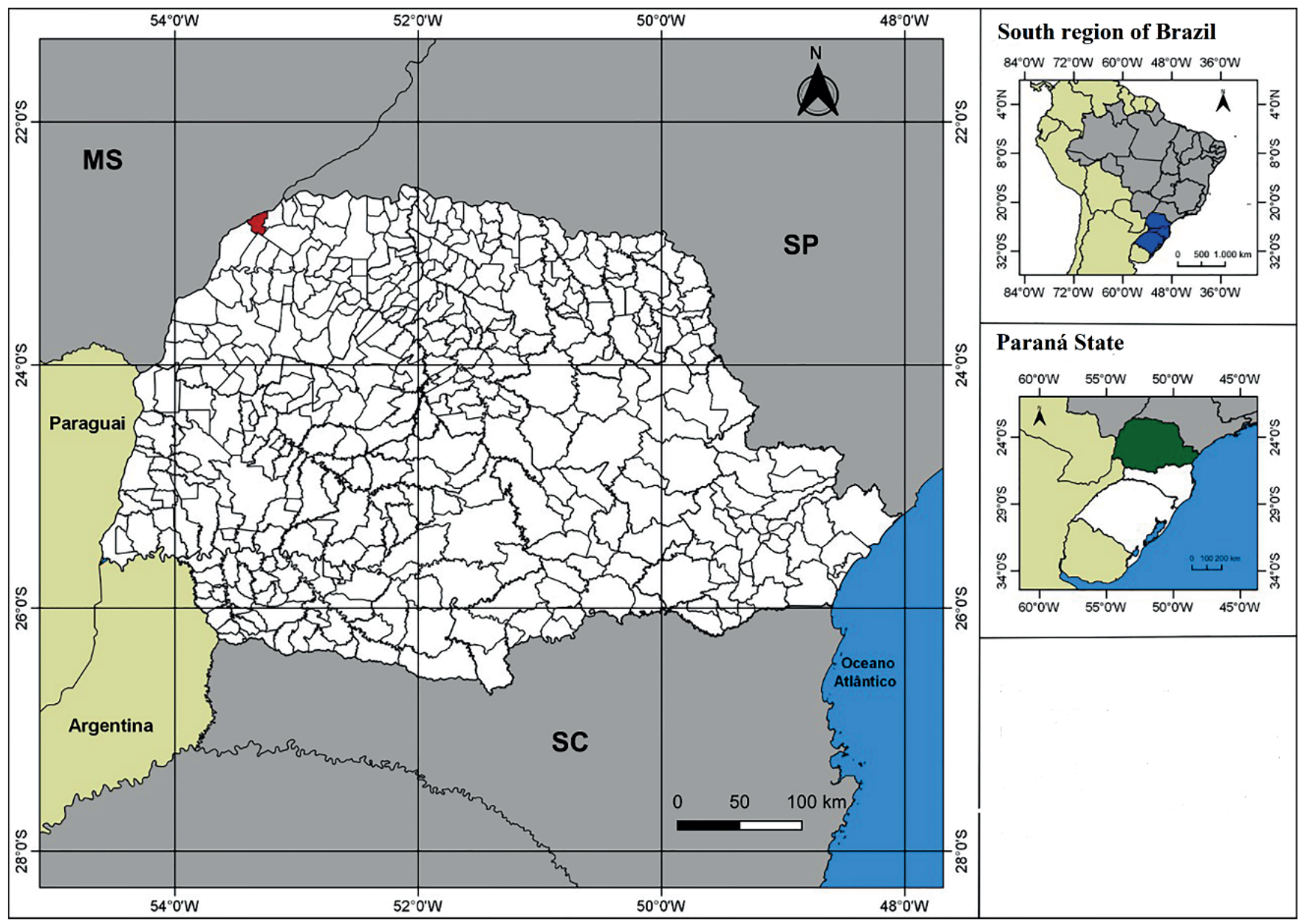

FIGURE 2: Geographical location of Paraná state (green); Highlighted: Porto Rico, Paraná (Red), Brazil, where P. tertius were collected in February 2002. (SC, Santa Catarina state; MS, Mato Grosso do Sul state; SP, São Paulo state). 
February 25, 2002. Voucher specimens can be accessed by request using the registration number CEJMSB 179 corresponding to the entomological collection of Prof. Dr. José Maria Soares Barata, Unesp, Araraquara, São Paulo, Brazil.

The identification of the P. tertius specimen was conducted in the Laboratory of Parasitology, Faculty of Pharmaceutical Sciences, São Paulo State University (Unesp), Araraquara, São Paulo, Brazil, based on the following criteria: body, small and somewhat dorsoventrally compressed; general color, light yellowish-brown with diffuse darker markings; setae, very short and inconspicuous; head, compressed dorsoventrally, slightly longer than the width at eye level; anteocular region, two or two and a half times the length of the postocular; head on a moderate slope behind the ocelli; anterolateral pronotum angles, very short; hemelytra attaining or almost attaining the apex of the abdomen; legs, short and stout without spines or tubercles (Figure 1) $)^{2,6,10}$.

The genus Psammolestes comprises three species and seems to be specialized in exploiting bird-nest ecotopes ${ }^{2}$. Phylogenetic analyses of $P$. tertius and $P$. coreodes suggest that this genus is monophyletic and can be considered a specialized lineage of the Rhodnius prolixus group because they share a common ancestor, which in turn highlights the paraphyly of the genus Rhodnius ${ }^{7,15}$. Based on a projection of its potential geographic distribution, $P$. tertius presents intermediate climatological limits and occurs at the highest altitudes compared to the other species of the genus ${ }^{12}$. The number of Brazilian states in which P. tertius occurred increased from 14 to 15 based on its presence in the state of Paraná, demonstrating that the biodiversity of these insects may have been underestimated and that their role in the epidemiology of Chagas disease remains uncertain.

\section{ACKNOWLEDGMENTS}

We thank the agents of epidemiological surveillance in the state of Paraná for collecting the specimen. We offer our thanks to the José Maria Soares Barata that who dedicated his life to the study of Triatomines and who collaborated with both specimen / knowledge. I am grateful for the support of Felipe Mendes Fontes and Natália Almeida Frota Santos with the making of the map.

\section{FINANCIAL SUPPORT}

Authors were supported by the Coordenação de Aperfeiçoamento de Pessoal de Nível Superior (CAPES) and by the Conselho Nacional de Desenvolvimento Científico e Tecnológico (CNPq).

\section{AUTHORS' CONTRIBUTION}

JO, JAR identified the specimen; WCJ and MTM preserved the specimen; VFP and JO wrote the manuscript; VFP and JO took the photos; JO, JAR, WCJ and MTM revised the text.

\section{CONFLICT OF INTEREST}

The authors declare that there is no conflict of interest.

\section{REFERENCES}

1. Souza ÉS, Fernandes RP, Galvão C, Paiva VF, Rosa JA. Distinguishing two species of Cavernicola (Hemiptera, Reduviidae, Triatominae) with matrix-assisted laser desorption ionization time-of-flight mass spectrometry. Acta Trop. 2019;198:105071.

2. Lent H, Wygodzinsky P. Revision of the Triatominae (Hemiptera, Reduviidae), and their Significance as Vectors of Chagas' Disease. Bull Am Mus Nat Hist. 1979;163:123-520.

3. Pinto C, Lent H. Sobre as espécies do genero Psammolestes Bergroth, 1911 (Hemiptera, Triatomidae). Ann Acad Bras Sci. 1935;7(4):333-7.

4. Pifano F. Anotaciones acerca del Psammolestes arthuri (Pinto, 1926) (Hemiptera, Heteroptera,Triatomidae) reduvideo hematofago encontrado en nidos de "cucarachero de monte (probablemente, Dendrocolaptidae) en un sector de los valles de Yaracuy. Gac Med Caracas. 1938;45:241-5.

5. Cazorla-Perfetti D. Psammolestes arthuri naturally infected with Trypanosoma cruzi found in sympatry with Rhodnius prolixus and Triatoma maculata on bird nests in Anzoátegui state, Venezuela. Saber. 2015;27(2):324-7.

6. Silva ANB, Diotaiuti L, da Câmara ACJ, Oliveira PIC, Galvão LMC, Chiari E, et al. First report of Psammolestes tertius Lent \& Jurberg, 1965 (Hemiptera, Reduviidae, Triatominae) in Rio Grande do Norte state, Brazil. Check List. 2018;14:1109.

7. Oliveira J, Alevi KCC, Ravazi A, Herrera HM, Santos FM, de AzeredoOliveira MTV, et al. New Evidence of the Monophyletic Relationship of the Genus Psammolestes Bergroth, 1911 (Hemiptera, Reduviidae, Triatominae). Am J Trop Med Hyg. 2018;99(6):1485-8.

8. Gomes ADC, Pereira JLA. Sobre o encontro de Cavernicola pilosa Barber, 1937, no Estado do Paraná, Brasil. Rev Saúde Pública. 1977;11(3):427-8.

9. Falavigna-Guilherme AL, Pavanelli GC, Silva SV, Costa AL, Araújo SM. Secondary triatomine species in dwellings and other nearby structures in municipalities under epidemiological surveillance in the State of Paraná, Brazil. Rev Panam Salud Pública. 2001;9(6):385-92.

10. Galvão C. Vetores da doença de Chagas no Brasil. $1^{\text {st }}$ ed. Sociedade Brasileira de Zoologia, Curitiba. 2014; 289p.

11. Cabrera R. Notas breves sobre Psammolestes tertius Bergroth, 1911 (Reduviidae: Hemiptera): un triatomino silvestre. Ana Fac Med Lima. 2006;67(4):345-65.

12. Gurgel-Goncalves R, Silva RB. Analysis of the geographical distribution of Psammolestes bergroth (Hemiptera: Heteroptera: Reduviidae: Triatominae) in South America, with new records of Psammolestes tertius Lent \& Jurberg. Zootaxa. 2009;2033(1):41-8.

13. Silva AM, Cristóvão EC, Silva VO, Luís Filho J, Santos JP, Silva JL, et al. Registro da ocorrência de Psammolestes tertius Lent \& Jurberg, 1965 (Hemiptera: Reduviidae: Triatominae) no estado do Paraná, Brasil. XX Congresso Brasileiro de Entomologia, Gramado, 05 a 10 de Setembro de 2004).

14. International Commission On Zoological Nomenclature. Amendment of Articles 8, 9, 10, 21 and 78 of the International Code of Zoological Nomenclature to expand and refine methods of publication. Zookeys. 2012;219:1-10.

15. Justi S, Galvão C. The evolutionary origin of diversity in Chagas disease vectors. Trends Parasitol. 2017;33(1):42-52. 